\title{
Response to the Letters from W. Kühn et al. and H. Griesser, K. Marquardt and B. Jordan on "Comments to the Publication of Munich Nomenclature III by the Cytology Coordination Conference" (Geburtsh Frauenheilk 2014; 74: 242-243)
}

Replik auf die Leserbriefe von W. Kühn et al. sowie von H. Griesser, K. Marquardt und B. Jordan zur "Stellungnahme zur Veröffentlichung der ,Münchner Nomenklatur III“ von der Koordinations-Konferenz Zytologie“ (Geburtsh Frauenheilk 2014; 74: 242-243)

Authors

Affiliation
P. Hillemanns, A. Schneider

Klinik für Frauenheilkunde und Geburtshilfe, Medizinische Hochschule Hannover, Hannover
Deutschsprachige Zusatzinformationen online abrufbar unter: www.thieme-connect.de/ ejournals/toc/gebfra
Bibliography

Dol http://dx.doi.org/

$10.1055 / \mathrm{s}-0034-1368643$

Geburtsh Frauenheilk 2014; 74:

637-638 @ Georg Thieme

Verlag KG Stuttgart · New York . ISSN 0016-5751

\section{Correspondence}

Prof. Dr. med.

Peter Hillemanns

Klinik für Frauenheilkunde

und Geburtshilfe

Medizinische Hochschule

Hannover

Carl-Neuberg-Straße 1

30625 Hannover

Hillemanns.Peter@

$\mathrm{MH}$-Hannover.de
The compilation of a new cytology nomenclature represents an important, long overdue step. It is an issue which the cytology societies have been discussing for years. When he was drawing up the agenda for the S3 Guideline on the Prevention of Cervical Cancer, the chairman of the S3 Guideline pointed out that an update of the Munich II Nomenclature was urgently needed, to allow among other things - the results of international studies to be adapted to a German context. The study group developing the new Guideline agreed with this recommendation, incorporated it in its PICO questions, and requested the members of cytology societies to modernize the cytology nomenclature as quickly as possible. After P.H. reported about the current state of affairs at the board meeting of the DGGG [German Society for Gynecology and Obstetrics] on November 9, 2012, the DGGG also endorsed the recommendation supporting a revision of the Munich Nomenclature.

When drawing up new morphological nomenclatures it is very important to consult with and involve as many professional societies and study groups as possible to already achieve a broad consensus in the early stages after extensive discussion. When the Bethesda system was being updated, 400 participants from 20 countries attended the 2001 Workshop, which also included internet bulletin boards with 1000 comments about the new system. We could learn a lot from the Americans; it is the only way in which potentially "the communication between cytologists, gynecologists, and patients could improve", something that was considered advisable in the second conclusion of Munich III. In the first conclusion, sensitivity is confused with positive predictive value: a new nomenclature cannot improve the sensitivity of the method if the method of investigation remains the same. All four conclusions of the Munich III article remain purely hypothetical but are sold to the reader as proven advantages of the new nomenclature. This contradicts the basic tenets of evidence-based medicine and cannot be allowed to stand unchallenged. But both of the letters to the editor do not address this crucial issue.

The two letters have confirmed us in our opinion that nomenclatures can and should be discussed. To begin with, we sent our original comment printed in this journal as a letter to the editor of the journal Der Frauenarzt. However, Der Frauenarzt refused to publish it, in the same way it has refused for years to publish similar topics and persons, thereby showing a complete disregard for the standard practice of the scientific community.

We welcome the discerning comments in the letter by W. Kühn et al. about the old category IIw and IIID and on differentiating a CIN 2 from a CIN 3 (in contrast to the American approach), as CIN 2 has a different biological significance. We also do not challenge the inclusion of glandular cell changes in the Munich III Nomenclature, even though this differentiated subcategorization of glandular cell changes (IIg, IIIg, IIIe, IVg, Vg, Ve) into probabilities and localizations (following the Bethesda system) is difficult to do and will doubtlessly require scientific evaluation in the next few years. By the way, we would like to note that HPV confirmation is the only method which permits the primary tumor to be allocated to either the cervix or endometrium in patients who have a diagnosis of "endometrioid adenocarcinoma".

Colposcopy is indisputably the most important method to investigate abnormal findings; however, the older the patient, the more common the presence of a type 3 transformation zone, where colposcopy will not help.

The ASCPC Consensus Guidelines outlining the proper procedure for atypical cytological and $\mathrm{HPV}$-positive findings are 29 pages long and include 17 algorithms; their complexity has not been even adequately considered in the clinical 
recommendations given in Munich III. Cytologists should therefore in future be guided, when making recommendations, by the S3 Guidelines which will soon be available and largely forgo the clinical recommendations of Munich III. The observation in the letter of Griesser et al. that the Munich III recommendations for investigating abnormal findings are necessary in order to integrate more meaningful diagnostic methods which will be available in the foreseeable future is illogical. If it is not yet clear which diagnostic methods will be used, then it would make more sense to refer to the S3 Guidelines. The guidelines are transparently compiled at considerable effort and with substantial financial/organizational support from the German Guideline Program in Oncology (German Cancer Society, German Cancer Aid, AWMF
[Association of the Scientific Medical Societies in Germany]) and include the views of a representative group of experts through contributions from different scientific societies with the methodological support of two internationally renowned specialist institutes for meta-analysis and GRADE interpretation and are regularly updated to take account of the most recent scientific data. In conclusion, we would like to state that the Munich III Nomenclature could potentially represent an improvement and that it would be useful to measure this. We, too, hope that it will be widely accepted and implemented, with regular re-evaluations of important quality parameters which have yet to be defined. Criticism is important for scientific debate and is conducive to the quest for improvement with all its positive connotations.

This article refers to:

Geburtsh Frauenheilk 2014; 74: 242-243 